\title{
Anthropometric Factors and Physical Condition Dominant Determinants Batting Skills in Softball
}

\author{
Arif Eka Saraya*; Sugiyanto Sugiyanto; Muchsin Doewes \\ Department of Sport Science, Sebelas Maret University of Surakarta, Indonesia \\ Email: arifekasaraya55@gmail.com
}

http://dx.doi.org/10.18415/ijmmu.v5i4.264

\begin{abstract}
Batting skills in softball requires several anthropometric factors and physical condition to play to improve skills. Anthropometric factors and physical condition, among others, height, arm length, arm muscle strength, hand-eye coordination, balance, and reaction time. This study aims to determine the anthropometric factors and the physical condition of the dominant determinant of batting skills in softball. This research approach uses a quantitative to design of confirmatory factor analysis. This study population is training student achievement softball in sports education university of riau. A sample of 100 people was obtained through a simple random sampling technique. The data used are taken through a series of tests of the independent and dependent variables. This research method through testing confirmatory factor KMO and Bartlett's Test analysis using SPSS. Results from this research is: factor of anthropometri dominant physical condition and determinants batting skill in game of softball is arm length with value 0,788 , arm muscle power with value 0,851 and time reaction of with value 0,737 . The conclusion of this research is: factor of anthropometri dominant physical condition and determinants batting skill in game of softball is arm length, arm muscle power and time reaction
\end{abstract}

Keywords: Anthropometric Factors; Physical Condition; Batting Skills;

\section{Introduction}

Softball is a small ball game born in the United States created by George Hancock in the city of Chicago in 1887. Softball in Indonesia is often called softball. Softball is the development of similar sports such as baseball or hardball. Although at first glance looks the same but softball and baseball have some pretty basic differences. Softball today has not been widely popularized when compared with other sports. This is because the facilities and infrastructure in this sport is quite expensive and not easily obtained by the public facilities such infrastructure such as field, bat bat, glove, softball ball, body protector, shoes and other attributes.

Softball is played by 9 players in one team. In softball games required basic techniques that must be mastered by players. The basic technique is to catch the ball, throw the ball, hit and run. Softball consists of two teams that meet each other. Both teams competed in different positions. One team as a 
difensive team or so-called team survive and the other team as offesive team or often referred to as a team of attackers in turn.

The main goal in softball is to collect the most points of each team for 7 innings. In the softball game basic batting skill and throw is very important to be mastered by the players. This is because the softball game starts with a pitcher and a better shot, which both can get points straight away. For batting skills techniques are very important in need by players. Batting is an essential ingredient for scoring points so that winning batting games without a team is unlikely to win a match. The main goal of a punch is to reach the base in front of him safely, create value, advance the player in front of him. In addition pitchers and other players also have to be skilled in doing throws, accuracy and speed in throwing is very important for players who are surviving to turn off the opponent.

The success of coaching improves the softball game skills especially batting skills requires various supporting components. Physical condition is one of the factors that determine performance or appearance, so the collapse of physical condition will lead to loss of skills (Sajoto., 1988: 99).

Mochamad Sajoto (1988) coaching physical conditions in sports that if an athlete wants to perform must have physical conditions such as: strength, endurance, muscular power, speed, coordination, flexibility, agility, balance, accuracy, reaction. Based on the physical condition component a softball athlete must know what components of physical condition affect their basic engineering skills especially on top and batting techniques which are strength, muscle explosive power, coordination, precision, and reaction.

How could a bat be able to hit the ball well if he lacked strength, good arm muscle power? So the result will not be able to bounce so far out of the field. If the blow is weak then the ball will be easily anticipated by the opposing player so he will easily be turned off before reaching the base. Then hand eye coordination and reactions in swinging the bat are also indispensable for a batter to be able to determine when the time is right for him to hit the ball thrown by the pitcher.

However, anatomical physical factors should also not be ignored. The anatomical factor or commonly said as a posture also provides its own advantages in sports. The selection of athletes to pursue a sport is not independent of these factors. The ideal body shape in accordance with the exercise is one of the conditions that can affect the achievement of sport. Sajoto (1988: 11) states "One aspect to achieve achievement in sports is a biological aspect that includes the structure and posture that is the height and length of limbs, large size, width and weight, and somatotype (body shape) ". A comparison of the length of the body parts to the height of each of these animals or briefly is called the anthropometric size ratio, which can provide relative value for each individual that can be compared with other individuals. Different height and arm factors can affect the outcome of the batting skills of each individual in the softball game.

\section{Methodology}

This research was conducted on campus of University of Riau Sports Education and Venue Softball Rumbai. The sampling technique using proportional random sampling is the method of sampling from the population with random, so that each member of the population is entitled to be a sample. The sample in this research is part of student in riau university sport education which amounts to 100 people.

The method used in this research is correlational research with confirmatory factor analysis design that is confirm the correlation of indicator variable with latent variable that determine the batting skill on softball. The collected data is then verified and tabulated to be quantitatively processed by: multivariate statistical factor analysis using SPSS computerized software so that it can be reduced to 
several factors only. Calculates the average donation value of each factor on the latent variable and the dependent variable. Describes the value and position of the average score of the dominant variable in the transformation of the importance-performance matrix.

The data analysis used in this research is Confirmatory Factor Analysis Technique which is a factor analysis technique which a priori based on known and predetermined theories and concepts (Gudono., 2012). The data will be processed using computerized statistical program with SPSS (Statistical Product and Service Solutions) system. According to Siswandari (2009: 156) the confirmatory factor analysis technique is exactly the same as the exploratory factor analysis technique by calculating the loading factor or the factor coefficient or lamda value $(\lambda i)$ similar to the regression coefficient value of $\beta \mathrm{i}$ ie the loding factor between the Xi indicator and the Fi factor formed. If the value of loading factor or lamda value $(\lambda \mathrm{i})$ obtained is greater than or equal to half $(\lambda \mathrm{i} \geq 0.5)$ or can be tested by test, and if the variable indicates significant value means $\mathrm{Xi}$ variable or instrument or item is legitimate to serve as member of the factor in question. The steps in conducting confirmatory factor analysis in this study are as follows:

\section{Test Prerequisite Analysis}

Prior to the process of data analysis by using factor analysis methods, first performed some prerequisite statistical tests are normality test in this study using One-Sample Kolmogorov-Smirnov Test method, processed using statistical computing software SPSS.

\section{Factor Analysis and Hypothesis Testing}

Factor analysis in this study is used to explain the relationship between a number of changes that are mutually independent from one another and to know the dominant factors in explaining a problem. In this study, the independent variables analyzed to determine the dominant factor determinants of batting skills are height, arm length, arm muscle power, hand eye coordination, balance, and reaction time. Hypothesis testing in this research is done by finding the correlation coefficient of each predictor, the regression equation $\mathrm{Y}$ on each predictor variable, the regression equation $\mathrm{Y}$ over all predictor variables together with multiple correlation coefficient. The calculation in testing the hypothesis as follows:

a. Kaiser-Meyer-Olkin and Bartlett's test of sphericity

b. Anti-image correlation test

c. Total variance explained test

d. Communalities or role factors

e. Component matrix (factor compiler dimension)

f. Component score coefficient matrix or factor dimension coefficient factor 


\section{Result \\ Factor Analysis and Hypothesis Testing Batting Skill Factor Analysis}

Factor analysis in this study was used to compile the factors of a set of variables that were considered feasible to be analyzed. The measurement sub-variable was determined long before the analysis was performed. Anthropometric factors are formed from height, and arm length while the physical factor is formed from arm muscle power, hand eye coordination, balance, and reaction time. The analysis to be used is R Factor to see the correlation between sub-variables, after obtained value from $\mathrm{R}$ factor then conducted Data Reduction to generate new variable which include some variables, from 6 variables that become dominant factor determinant of hitting skill will be tested whether everything become important or only partial variables are feasible to be analyzed and grouped into major factors. However, before analyzing the data using factor analysis method, it is necessary to perform a preliminary analysis test.

\section{A. Factor Analysis I}

The magnitude of the correlation between the independent variables measured has a value between 0 and 1 , to express the strong relationship the required KMO-MSA number should be $\geq 0.5$ with the probability value (Sig.) Should be $<0.05$. This shows that the collection of variables in this study is significant and can be further processed. Further data will be processed and processed by looking at the magnitude of partial correlation between two variables with still include all variables. This detection is done by looking at Anti Image Correlation resulting in Measure of Sampling Adequacy (MSA) value between 0 and 1 . If MSA $=1$ variable can be predicted without error by other variable, if MSA $>0.5$ variable can still be predicted and can be analyzed further and when the MSA $<0,5$ then the variable must be eliminated and cannot be further analyzed or removed from the set of other variables.

\section{Table 1 Result KMO and Bartlett's Test Anthropometric Factors and Physical Condition Dominant Determinants Batting Skills.}

\begin{tabular}{lrr}
\hline Kaiser-Meyer-Olkin Measure of Sampling Adequacy. & .560 \\
Bartlett's Test of Sphericity & Approx. Chi-Square & 75.465 \\
& Df & 12 \\
& Sig. & .000 \\
\hline
\end{tabular}

The results obtained Kaiser-Meyer-Olkin Measure of Sampling Adequacy abbreviated KMOMSA and Bartlett's Test of Sphericity. The result of KMO-MSA test on 6 tested variables was $0.560>0.5$ while Bartlett's Test of Sphericity showed Approximate Chi-square number of 75,465 with Degree of Freedom (df) 12 and significance of 0.000. The magnitude of the correlation between the measured 
independent variables has a value between 0 and 1 , to express a strong relationship the KMO-MSA number should be above 0.5 and with the probability value (Sig.) Should be $<0.05$. This shows that the collection of variables in this study is significant and can be further processed.

Table 2 Result Anti-image Matrices Correlation Anthropometric Factors and Physical Condition Dominant Determinants Batting Skills.

\begin{tabular}{|c|c|c|c|c|c|c|}
\hline Anti-image Correlation & Height & Arm length & $\begin{array}{l}\text { Power arm } \\
\text { muscles }\end{array}$ & $\begin{array}{l}\text { Hand eye } \\
\text { coordination }\end{array}$ & Balance & $\begin{array}{l}\text { Reaction } \\
\text { time }\end{array}$ \\
\hline Height & $.364^{2}$ & -.415 & -.327 & .101 & .068 & -.312 \\
\hline Arm legth & -.415 & $.632^{3}$ & -.167 & .113 & -.056 & .125 \\
\hline Power arm muscles & -.327 & -.167 & $.712^{\mathrm{a}}$ & -.056 & -.047 & .185 \\
\hline Hand eye coordination & .101 & .113 & -.056 & $403^{x}$ & -.180 & -.162 \\
\hline Balance & .068 & -.056 & -.047 & -.180 & $.444^{2}$ & .155 \\
\hline Reaction time & -.312 & .125 & .185 & -.162 & .155 & $.517^{a}$ \\
\hline
\end{tabular}

In the Anti Image matrices correlation tab, there are three variables that have MSA value below 0.50 each are height $(0,364)$ hand eye coordination $(0,403)$, and balance $(0,444)$ which have to be redadicated and must be removed or eliminated because no significant for follow-up test.

The next step is to reduce the variable with factor analysis II by not including the variable height, hand eye coordination and balance because in the first step of analysis both have MSA value below 0.5 which means that factor is not eligible to be included in factor analysis II.

After performing the prerequisite factor analysis test, the next step is to test the advanced factor analysis by reducing or eliminating the factors that have MSA value below 0.5, ie the height (0.364) of eye eye coordination $(0.403)$, and balance $(0,444)$. The step advanced test is as follows: 


\section{B. Factor Analysis II}

\section{Table 3 Result KMO and Bartlett's Test Anthropometric Factors and} Physical Condition Dominant Determinants Batting Skills

\begin{tabular}{lrr}
\hline Kaiser-Meyer-Olkin Measure of Sampling Adequacy. & .602 \\
Bartlett's Test of Sphericity & Approx. Chi-Square & 68.547 \\
& Df & 4 \\
& Sig. & .000 \\
\hline
\end{tabular}

From the table above, the results of second factor analysis obtained Kaiser-Meyer-Olkin Measure of Sampling Adequacy (KMO-MSA) and Bartlett's Test of Sphericity against 7 variables tested obtained value 0.602> 0.5 while Bartlett's Test of Sphericity indicates Approximate Chi-square is 68,547 with Degree of Freedom (df) 4 and significance level 0,000. The magnitude of the correlation between the measured independent variables has a value between 0 and 1, to express a strong relationship the KMOMSA number should be above 0.5 and with the opportunity value (Sig.) Should be $<0.05$. This shows that the collection of variables in this study is significant and can be further processed.

Table 4 Result Anti-image Matrices Correlation Anthropometric Factors and Physical Condition Dominant Determinants Batting Skills.

\begin{tabular}{lrrr}
\hline Anti-image Correlation & \multicolumn{1}{l}{ Arm legth } & Power arm muscles & \multicolumn{1}{l}{ Reaction time } \\
\hline Arm legth &. $\mathbf{6 7 7}^{\mathbf{a}}$ & -.324 & .118 \\
Power arm muscles & -.324 &. $\mathbf{7 2 1 ^ { \mathbf { a } }}$ & -.228 \\
Reaction time & .118 & -.228 & $\mathbf{. 6 0 3}^{\mathbf{a}}$ \\
& & & \\
a. Measures of Sampling Adequacy(MSA) & &
\end{tabular}

In Anti Image Matrices tabulation there is no variable that has MSA value below 0,50 which means that all variables can be tested further using extraction process with Principal Component Analysis method that yields value of Communalities. 
Table 5 Result Communalities Anthropometric Factors and Physical Condition

Dominant Determinants Batting Skills

\begin{tabular}{lcc}
\hline Variable & Initial & Extraction \\
\hline Arm legth & 1.000 & .660 \\
Power arm muscles & 1.000 & .765 \\
Reaction time & 1.000 & .578
\end{tabular}

Extraction Method: Principal Component Analysis.

From the table above can be seen the initial value and extraction value. The initial value reflects the role or contribution if variable compiler factors individually form these factors, while the results of comunalities for each variable is in the extraction column. The extraction value describes the percentage of roles or contributions of each dimension or sub-variable of the factor factors individually to the factor. It also means the number in the extraction column shows the percentage of rotated component matrix. From the table above is known that the role of the largest dimension is sub-variable power arm muscles, with the value of 0.765 or $76.5 \%$ and the smallest is the reaction time with value of 0.578 or $57.8 \%$. Then to know the donation of each variable on each component, need to do the rotation process that produces Matrix component as above.

\begin{tabular}{|c|c|}
\hline \multicolumn{2}{|c|}{ Condition Dominant Determinants Batting Skills. } \\
\hline \multirow{2}{*}{ Variabel } & Component \\
\hline & 1 \\
\hline Arm legth & .788 \\
\hline Power arm muscles & .851 \\
\hline Reaction time & .737 \\
\hline
\end{tabular}

Extraction Method: Principal Component Analysis. .

a. I components extracted.

Based on the results of Component Matrix Analysis of anthropometric and physical factors determining upper throwing skills and hitting skills, it turns out there are three components of factors have a value of $\geq 0.5$ that is the length of the arm, arm muscle power and reaction time. This means that the dimensions of the anthropometric and physical factors comprising the variable arm length, arm muscle power and reaction time are members of the anthropometric variable factor and the physical condition of the determinant of the batting skills. 


\section{Discussion}

Based on the result of hypothesis test about anthropometry factor analysis and physical condition of determinant of hit skill, there are 3 variables that must be eliminated from analysis factor I or excluded from dominant analysis factor or ( $\mathrm{H} 0$ rejected) because it has value of $\mathrm{MSA} \leq 0.5$ that is variable height with value equal to 0,364 , hand eye coordination with value equal to 0,403 and balance with value 0,444 . After that followed by factor analysis II so found anthropometry factor and physical condition that determine skill upper ( $\mathrm{H} 0$ accepted) or that have value of matrix component $\geq 0,5$ is:

a. length of arm with 0.788 matrix component value

b. power arm muscle with a 0.851 matrix component value

c. reaction time with 0.737 matrix component value

The results of this study provide an illustration that anthropometry factors and physical conditions that determine the skills of the top throw are the arm length, arm muscle power, hand eye coordination, and balance.

The result of factor analysis in this research is calculated using KMO and Bartlett's Test method with SPSS computerized statistical software, from the explanation and data analysis that has been done, it is obtained by anthropometry factor variable and physical determinant of skill skill consisting of 4 indicator variables. The result of statistical test of factor analysis of all variables is anthropometry factor and the dominant physical condition in determining the skill of batting is arm length with value 0,788, power of arm muscle with value 0,851 and reaction time with value 0,737 Because of three independent variable have correlation value positive and is above $\geq 0.5$ based on the value of the matrix component. Then it can be concluded that the greater the component matrix value of the independent variables will further instigate the softball players in performing the batting skills.

While anthropometry factor and physical condition which have low correlation value or less dominant in determining skill skill is height height with value equal to 0,364 , hand eye coordination with value equal to 0,403 and balance with value 0,44 thus all three factors must be eliminated or is excluded from the further analysis test as it does not have sufficient value for the further test.

\section{Conclusion}

Based on the results of the analysis of all anthropometry factors and the dominant physical condition that becomes the determinant of the skill of upper skill and batting skills on softball can be summed up as follows:

The anthropometry factor and the dominant physical condition determining the hitting skills on the softball game are the arm lengths with a value of 0.788 , arm muscle power with a value of 0.851 and reaction time with a value of 0.737 . 


\section{References}

Bompa, Tudor O. (1990). Theory and Methodology of Training: the Key to Athletic Performace. Second Edition Debuque Iowa: Kendall/Huns Publishing Company. 1994. Theory and Methodology of training, Dubuque, Iowa: Hunt Publishing Company.

David, Gallahue, L., \& John, Ozmun, C. (1998). Understanding Motor Development: Infants, Childern, Adolencents, Adults".

Diane L. Potter, EdD dan Gretchen A. Brockmeyer, EdD. (1999). Softball Step To Succes. United States: Human Kinetics.

Djoko Pekik Irianto. (2007). Panduan Gizi Lengkap Keluarga dan Olahragawan. Yogyakarta: C.V ANDI OFFSET.

Drajat J. (2001). Analisis Biomekanika Softball. Jakarta: Jurnal KONI Pusat (accesed 15/4/2015).

Emzir. (2008). Metodologi Penelitian Pendidikan Kuantitatif \& Kualitatif. Jakarta: Rajagrafindo Persada.

Garman J. (2001). Softball Skill and Drill. United States: Humans Kinetics Publisher, Inc.

Gudono. (2012). Analisis Data Multivariat.Yogyakarta: BPFE.

Harsono. (1988). Coaching dan Aspek-aspek psikologis dalam coaching. Jakarta: Derjendikti.

Hatmisari, Dwi. (2005). Panduan Penetapan Parameter Tes. Jakarta.

Houseworth dan Rivkin. (1995). Softball Coaching Efective. American. Human Kinetics Publisher, Inc.

Ismaryati. (2008). Tes dan Pengukuran Olahraga. Surakarta: UNS Press.

Kirkendall. (1987). Measurement and Evaluation for Physical Educators (second division). Human Kinetics Publishers, Ine Champaingn, Ilinois.

Noren R. (2005). Softball Fundamentals. New Zealand: Humans Kinetics Publishers, Inc.

Nurhasan. (2000). Tes dan Pengukuran Pendidikan Olahraga. FPOK-UPI

-----------. (2007). Tes dan Pengukuran Keolahragaan. Bandung.

Parno. (1992). Olahraga Pilihan Softball. Jakarta: Depdikbud.

Rahmadini. (2007). Ilmu Otot Umum. Jakarta: FK UI.

Sajoto, M. (1988). Pembinaan Kondisi Fisik Dalam Olahraga. Housten.

Prize Offset.

(1995). Pembinaan Kekuatan Kondisi Fisik Dalam Olahraga. Semarang: Effhar \& Dahara

Santoso, Singgih. (2012). Aplikasi SPSS pada Statistik Multivariat. Jakarta: PT Elex Komputindo.

Siswandari. (2011). Statistika Computer Basic. Cetakan 2. Surakarta. LPP UNS dan UNS Press.

Sugiyono. (2008). Statistik Untuk Penelitian. Bandung: Alfabeta.

Suharsimi Arikunto. (2002). Prosedur Penelitian Suatu Pendekatan Praktek. Jakarta: Rineka Cipta. 


\section{Copyrights}

Copyright for this article is retained by the author(s), with first publication rights granted to the journal.

This is an open-access article distributed under the terms and conditions of the Creative Commons Attribution license (http://creativecommons.org/licenses/by/4.0/). 